\title{
Hews and hinotes
}

To Members of the American Neurologtcal Association: The Council announces that the thirty-first Annual Meeting will be held in Philadelphia on Thursday, Friday and Saturday, June rst, $2 d$ and $3 \mathrm{~d}$. Therre will be two sessions daily, from Io a.m. to I p.m. and from 2:20 to 5 p.m.

If it is your intention to contribute a paper, your attention is called to a clause of Article VII of the Constitution, which states: "The reader of a paper shall not exceed twenty minutes in the presentation of his paper, and no one shall speak longer than five minutes in the discussion of a paper."

It is the earnest request of the Council that you will, if practicable, present a verbal abstract of your paper instead of reading it in full.

Your attention is called to another clause of Article VII, which states: "Members must send the titles and abstracts of their papers to the Secretary at least six weeks before the Annual Meeting." Titles and abstracts must, therefore, be received by the Secretary on or before April 2oth.

The Council recommends the following candidates for election to active membership: Dr. Wm. G. Spratling of Sonyea, Dr. L. Pierce Clark of New York, Dr. F. H. Weisenburg of Philadelphia, Dr. Alfred Gordon of Philadelphia, Dr. William Pickett of Philadelphia, Dr. Charles S. Potts of Philadelphia. The annual dinner will be held on Friday evening, June 2. The Council announces that the annual dues for 1905 will be five dollars. Very respectfully yours,

Graeme M. Hammond, Sec'y.

The National Association for the Study of Epilepsy and the Cure and Treatment of Epileptics.-There is a widespread belief that the Transactions of the Association at the reecnt meeting should be printed. The very creditable publication, showing the transactions of the Association at the meeting held in Washington in IgOI, has set a standard which it is hard to equal. I have the opinion of the President of the Association and some of the nembers of the Executive Committee that we should try to issue a volume of about the same size and general appearance, but that we may, if needs require, omit the illustrations.

We would attempt to include an outline of the proceedings at the meetings of 1902 and 1903.

The cost of publication will be near $\$ 400$. Towards the amount the following subscriptions have already been offered: Mr. Letchworth, \$25; Dr. Spratling, \$25; Dr. Bullard, \$25; Dr. Flood, \$ro.

Your coöperation is needed. Will you kindly contribute as liberally as possible? You will be entitled to one copy of the "Transactions" for every dollar you contribute; but it is hoped that you will leave all but one copy in the hands of the Secretary and instruct him to use such proceeds as he may realize from them for the needs of the Association.

EveretT Flood, Sec. and Treas. 